\title{
PENERAPAN METODE PENEMUAN TERBIMBING DENGAN MENGOPTIMALKAN PENGGUNAAN LEMBAR KERJA SISWA (LKS) UNTUK MENINGKATKAN HASIL BELAJAR MATEMATIKA SISWA KELAS VI SD NEGERI 39 MATARAM
}

\author{
Baiq Nurhayatun \\ SD Negeri 39 Mataram \\ baiqnurhayatunhayatun@gmail.com
}

\begin{abstract}
The purpose of this study was to determine the increase in mathematics learning outcomes through the application of the guided discovery method by optimizing the use of student worksheets for Class VI students of SD Negeri 39 Mataram for the 2019/2020 academic year. This research is a classroom action research. The subjects in this study were 37 students of class VI SD Negeri 39 Mataram with 20 male students and 17 female students. Data collection tecbniques used were observation, documentation, and tests. Observation is used to collect interest in learning data. The test is used to measure learning achievement in Mathematics subjects. The data analysis used was descriptive qualitative and quantitative descriptive. The results showed that: Guided discovery method can improve mathematics learning outcomes of mixed arithmetic operation material in grade VI SD Negri 39 Mataram. Mathematics learning outcomes have increased with learning completeness $61.16 \%$ in the initial conditions to $78.38 \%$ in cycle I to $91.89 \%$ in cycle II classical student learning completeness has been acbieved. From the increase in student activity, student activity increased from the acquisition score of $79.17 \%$ in cycle I, to $91.67 \%$ in cycle II. Based on data analysis, it was found that student activity in the learning process of Mathematics with the guided discovery method, the most dominant was working using tools / media, listening to / paying attention to teacher explanations, and discussions between students / between students and teachers. So it can be said that student activity can be categorized as active. Meanwhile, teacher activity increased from the acquisition score of $77.78 \%$ in the first cycle to $95.83 \%$ in the second cycle. For teacher activities during learning have implemented the steps of the guided discovery method by optimizing the use of student worksheets properly.
\end{abstract}

Keywords: Guided Discovery Methods and Mathematics Learning Outcomes

\begin{abstract}
Abstrak : Tujuan dalam penelitian ini adalah untuk mengetahui peningkatan hasil belajar Matematika melalui penerapan metode penemuan terbimbing dengan mengoptimalkan penggunaan lembar kerja siswa (LKS) Siswa Kelas VI SD Negeri 39 Mataram Tahun Pelajaran 2019/2020. Penelitian ini merupakan penelitian tindakan kelas. Subjek dalam penelitian ini sebanyak 37 siswa kelas VI SD Negeri 39 Mataram dengan jumlah laki-laki 20 siswa dan perempuan 17 siswa. Teknik pengumpulan data yang digunakan adalah observasi, dokumentasi, dan tes. Observasi digunakan untuk mengumpulkan data minat belajar. Tes digunakan untuk mengukur prestasi belajar mata pelajaran Matamatika. Analisis data yang digunakan yaitu deskriptif kualitatif dan deskriptif kuantitatif. Hasil penelitian menunjukkan bahwa: Metode penemuan terbimbing dapat meningkatkan hasil belajar Matematika materi operasi hitung campuran pada siswa kelas VI SD Negri 39 Mataram. Hasil belajar Matematikan mengalami peningkatan dengan ketuntasan belajar 61,16\% pada kondisi awal menjadi 78,38\%
\end{abstract}

As-Sabiqun : Jurnal Pendidikan Islam Anak Usia Dini

Volume 2, Nomor 2, September 2020; 98-112

https://ejournal.stitpn.ac.id/index.php/assabiqun 
pada siklus I menjadi $91,89 \%$ pada siklus II ketuntasan belajar siswa secara klasikal telah tercapai. Dari aktivitas siswa mengalami peningkatan, aktivitas siswa meningkat dari skor perolehan 79,17\% pada siklus I, menjadi 91,67\% pada siklus II. Berdasarkan analisis data, diperoleh aktivitas siswa dalam proses pembelajaran Matematika dengan metode penemuan terbimbing yang paling dominan adalah bekerja dengan menggunakan alat/media, mendengarkan/memperhatikan penjelasan guru, dan diskusi antar siswa/antara siswa dengan guru. Jadi dapat dikatakan bahwa aktivitas siswa dapat dikategorikan aktif. Sedangkan aktivitas guru meningkat dari skor perolehan 77,78\% pada siklus I, menjadi $95,83 \%$ pada siklus II. Untuk aktivitas guru selama pembelajaran telah melaksanakan langkah-langkah metode penemuan terbimbing dengan mengoptimalkan penggunaan LKS dengan baik.

Kata Kunci: Metode Penemuan Terbimbing dan Hasil Belajar Matematika

\section{PENDAHULUAN}

Tujuan pembelajaran Matematika menurut Kemendikbud 2013 yaitu (1) meningkatkan kemampuan intelektual, khususnya kemampuan tingkat tinggi siswa, (2) membentuk kemampuan siswa dalam menyelesaikan suatu masalah secara sistematik, (3) memperoleh hasil belajar yang tinggi, (4) melatih siswa dalam mengkomunikasikan ideide, khususnya dalam menulis karya ilmiah, dan (5) mengembangkan karakter siswa. Tujuan pembelajaran matematika tingkat SD/MI adalah agar siswa mengenal angkaangka sederhana, operasi hitung sederhana, pengukuran, dan bidang.

Di dalam kehidupan sehari-hari kita tidak terlepas dari Matematika (Faizi, 2013:70). Mulai dari benda-benda sekitar yang erat hubungannya dengan Matematika seperti jam, timbangan dan lain-lain, hingga aktivitas-aktivitas yang menggunakan Matematika misalnya saja kegiatan jual beli. Oleh karena itu Matematika mempunyai peran yang amat penting dalam kehidupan.

Dalam dunia pendidikan, proses belajar mengajar merupakan suatu kegiatan untuk melaksanakan kurikulum, agar dapat mencapai tujuan pendidikan yang telah ditetapkan. Tujuan pendidikan mengantarkan siswa pada perubahan-perubahan tingkah laku, baik intelektual, moral maupun sosial. Tujuan pengajaran adalah rumusan kemampuan yang diharapkan dimiliki siswa setelah menempuh berbagai pengalaman belajar.

Pembelajaran Matematika adalah proses yang kompleks dan mengandung banyak variabel dan semua variabel saling berhubungan, kemudian matematika yang 
dibicarakan di SD adalah matematika dengan pengertian materi dan pola pikirnya telah dipilih dan disesuaikan proses kemampuan siswa walaupun obyek matematika adalah abstrak tetapi dalam pengajarannya dapat dimulai dari objek yang kongkrit (Hidayat, 2001). Oleh karena itu guru matematika harus lebih berhati-hati dalam mendidik siswanya dan dapat meningkatkan minat siswa dalam pembelajaran matematika, serta sedapat-dapatnya menarik diri guna memberikan kesempatan kerja kepada siswa untuk belajar mandiri yang bisa diterapkan bagi siswa yang paham dengan materi yang diberikan, tetapi bagi yang belum atau masih kurang akan mengalami kesulitan terutama siswa yang tidak berani bertanya. Dalam situasi seperti ini, siswa masih perlu bimbingan dalam proses belajar mengajar, karena itu perlu dikaji masalah dan diketahui penyebabnya.

Menurut Slameto (1998), dalam tugas pokok guru adalah mendidik, guru harus dapat menbantu siswa-siswanya agar mencapai kedewasaan secara optimal sesuai dengan tujuan pendidikan, namun selain mendidik guru juga membimbing dimana sebagai pembimbing, guru merupakan tangan pertama dalam usaha membantu memecahkan kesulitan siswa. Dalam hal ini, perlu bimbingan dalam mengajar matematika dengan latihan soal agar siswa dapat meningkatkan hasil belajar matematikanya.

Dari hasil pengalaman penulis sebagai guru dan peneliti, selama mengajar sebagai guru kelas VI di SD Negeri 39 Mataram, bahwa hasil belajar Matematika siswa dengan ketuntasan hanya $62,516 \%$ artinya masih kurang terutama pada materi operasi hitung campuran. Hal ini berarti pemahaman siswa masih kurang, dan penulis sebagai guru dan peneliti kurang banyak memberikan latihan soal. Kemudian dalam membimbing yang diberikan pada siswa yang rajin bertanya sedangkan yang diam tidak mendapat perhatian. Jadi untuk mengatasi hal tersebut, maka guru dalam mengajar harus menggunakan metode yang tepat dan sesuai dengan kemampuan peserta didik agar dapat mematangkan pengetahuannya tentang konsep operasi hitung campuran dan sifatsifat matematika yang digunakan dalam operasinya dan mempelajari cara-cara membimbing siswa untuk menemukan konsep, memahami algoritma, dan menimbulkan keterampilan mengolah operasi bilangan pecahan.

Untuk meningkatkan kemampuan pemecahan masalah Matematika, perlu dirancang pembelajaran yang menekankan pada permasalahan untuk siswa dapat 
menemukan sendiri aturan-aturan yang menghasilkan informasi baru. Dalam pembelajaran Matematika yang memanfaatkan permasalahan, siswa akan terdorong untuk mengeksplorasi pengetahuan atau ide-ide yang relevan agar menemukan berbagai strategi atau solusi suatu permasalahan. Sehingga siswa akan menjadi lebih mudah dalam memahami konsep-konsep matematika. Salah satu model pembelajaran yang mengaitkan siswa untuk dapat menemukan suatu informasi baru yaitu model penemuan terbimbing.

Model pembelajaran penemuan terbimbing berupaya membantu siswa untuk meningkatkan kemampuan pemecahan masalah. Dengan menggunakan model penemuan terbimbing baik diberikan kepada siswa yang berkemampuan sedang dan juga tinggi.

Pembelajaran dengan model penemuan terbimbing menuntut keaktifan, ketekunan, kreativitas, dan ketrampilan proses dalam pemecahan masalah. Dengan demikian proses pembelajaran melibatkan partisipasi siswa secara optimal (Effendi, 2012:8).

Menurut Hudojo (dalam Effendi, 2012: 2), jika siswa terlibat aktif dalam menemukan prinsip dasar, maka siswa dapat memahami konsep secara baik, mengingat materi dan mampu mengaplikasikannya kedalam konteks yang lain. Selain itu juga Model Penemuan Terbimbing dapat meningkatkan minat siswa untuk mempelajari Matematika. Dengan menggunakannya model penemuan terbimbing diharapkan kemampuan siswa dalam memecahkan masalah matematika meningkat dan siswa dapat dengan terampil menggunakan pengetahuan yang telah diperolehnya untuk memecahkan suatu masalah Matematika.

Dalam memberikan bimbingan kepada siswa untuk menemukan konsep atau terutama prinsip (rumus, sifat) guru dapat menggunakan media Lembar Kerja Siswa (LKS), karena didalam LKS memuat hal-hal yang perlu diketahui siswa dan pertanyaan-pertanyaan atau masalah-masalah yang harus dipecahkan oleh siswa. Melalui pengoptimalan LKS siswa diharapkan benar-benar aktif dan mandiri sehingga dapat menyerap dan mengingat lebih lama terhadap apa yang dipelajarinya. 
Berdasarkan latar belakang masalah tersebut penulis tertarik untuk melakukan penelitian dengan tujuan untuk memberikan solusi terkait kurangnya kemampuan pemecahan masalah Matematika. Penulis bermaksud untuk melakukan suatu penelitian dalam bentuk penelitian tindakan kelas dengan judul "Penerapan metode penemuan terbimbing dengan mengoptimalkan penggunaan Lembar Kerja Siswa (LKS) untuk meningkatkan hasil belajar Matematika Siswa Kelas VI SD Negeri 39 Mataram Tahun Pelajaran 2019/2020"

Berdasarkan latar belakang permasalahan, maka rumusan masalah dalam penelitian ini adalah: Bagaimanakah peningkatan hasil belajar Matematika melalui penerapan metode penemuan terbimbing dengan mengoptimalkan penggunaan lembar kerja siswa (LKS) Siswa Kelas VI SD Negeri 39 Mataram Tahun Pelajaran 2019/2020?

Tujuan dalam penelitian ini adalah untuk mengetahui peningkatan hasil belajar Matematika melalui penerapan metode penemuan terbimbing dengan mengoptimalkan penggunaan lembar kerja siswa (LKS) Siswa Kelas VI SD Negeri 39 Mataram Tahun Pelajaran 2019/2020.

\section{METODE PENELITIAN}

\section{Subjek Dan Lokasi Penelitian}

Penelitian ini berlokasi di SD Negeri 39 Mataram. Jalan Dewi Sartika No.13, Monjok Baru Kec. Selaparang, Kota Mataram. Dan penelitian ini akan dilakukan dengan sasaran semua siswa kelas VI SD Negeri 39 Mataram tahun ajaran 2019/2020 dengan jumlah sasaran 37 orang siswa yang terdiri dari 17 siswa perempuan dan 20 siswa lakilaki.

\section{Sumber Dan Jenis Data}

Sumber data dalam penelitian ini adalah tes hasil belajar siswa kelas VI SD Negeri 39 Mataram Tahun Pelajaran 2019/2020. Jenis data yang akan didapatkan melalui penelitian ini adalah data kuantitatif dan data kualitatif. 


\section{Prosedur Penelitian}

Penelitian ini akan dilakukan dengan menggunakan desain penelitian tindakan kelas yang bermitra dengan teman orang guru di SD Negeri 39 Mataram. Penelitian tindakan kelas ini akan dilaksanakan berdasarkan indikator ketercapain pada tiap siklus. Dimana tiap siklus mempunyai 4 tahapan, yaitu: Planning (perencanaan), Action (Tindakan), Observation (pengamatan), Reflection.

Adapun langkah-langkah pelaksanaan penelitian tindakan kelas ini adalah sebagai berikut:

a. Tahap Perencanaan

1) Mengidentifikasi masalah, serta pengambilan data pre-tes, kemudian merumuskan masalah.

2) Menetapkan alternatif pemecahan masalah yaitu dengan menerapkan pendekatan kontekstual sebagai solusi pemecahan masalah.

3) Merencanakan pembelajaran yang akan diterapkan dalam PBM

4) Menentukan materi pokok pembelajaran

5) Mengembangkan skenario pembelajaran

6) Menyusun lembar kerja siswa

7) Menyiapkan alat dan bahan percobaan

8) Membuat instrumen penilaian

9) Menyusun format observasi pembelajaran.

b. Pelaksanaan Tindakan

Kegiatan yang dilaksanakan pada tahap ini adalah melaksanakan semua yang telah direncanakan di atas, yaitu :

1) Mengadakan pretes untuk mengetahui tingkat prestasi belajar siswa sebagai acuan untuk menentukan alternatif pemecahan masalah pada siklus 1 .

2) Melaksanakan proses belajar mengajar di kelas dan luar kelas dengan menerapkan metode penemuan terbimbing dengan mengoptimalkan penggunaan lembar kerja 
siswa (LKS), sesuai dengan rencana yang akan dituangkan dalam skenario pembelajaran.

3) Melaksanakan observasi selama proses belajar mengajar berlangsung.

4) Melaksanakan tes setelah satu siklus selesai dilaksanakan dengan menggunakan tes yang sudah didesain.

c. Pengamatan (observasi)

Peneliti sebagai guru dan akan dibantu oleh 1 orang observer (guru mitra) untuk mengamati proses pembelajaran dan menilai kemampuan siswa dalam bekerja untuk menyelesaikan tugas dalam kelompoknya melalui lembar observasi guna melihat kemampuan psikomotorik siswa, dan kemampuan kognitif diperoleh dari hasil tes.

d. Refleksi

Pada tahap ini peneliti menganalisa data yang diperoleh berupa hasil tes, hasil observasi untuk melihat apakah pembelajaran yang dilakukan dapat meningkatkan prestasi belajar siswa, terutama pada pembelajaran Matematika. Jika data yang diperoleh dari siklus I, masih terlihat adanya kekurangsempurnaan maka perlu dilakukan perbaikan pada pelaksanaan pembelajaran siklus I pada siklus berikutnya.

\section{Instrumen Penelitian}

Berdasarkan judul penelitian, instrumen yang digunakan dalam penelitian ini adalah berbentuk tes dan non tes.

1. Tes

Tes yang diberikan dalam penelitian ini adalah berupa soal pilihan ganda. Tes yang diberikan terdiri atas 2 katagori yaitu:

a. Pre tes

Pre tes diberikan untuk mengetahui tingkat pemahaman siswa sebelum menggunakan metode penemuan terbimbing dengan mengoptimalkan penggunaan lembar kerja siswa (LKS). 
b. Post tes

Post tes diberikan untuk mengetahui tingkat pemahaman siswa setelah menggunakan metode penemuan terbimbing dengan mengoptimalkan penggunaan lembar kerja siswa (LKS).

2. Non tes

Non tes yaitu berupa lembar observasi. Lembar observasi ini digunakan untuk mengetahui tingkat aktifitas siswa dan guru selama proses pembelajaran berlangsung dengan menggunakan metode penemuan terbimbing dengan mengoptimalkan penggunaan lembar kerja siswa (LKS)

\section{Indikator Ketercapaian}

Untuk mengetahui keberhasilan belajar siswa digunakan kriteria sebagai berikut :

1. Jika $85 \%$ dari jumlah peserta didik telah mencapai kriteria ketuntasan minimal $\geq 77$.

2. Aktifitas siswa minimal aktif dan selalu mengalami peningkatan pada tiap siklusnya.

Jadi indikator keberhasilan penelitian ini dikatakan berhasil bila adanya peningkatan prestasi hasil belajar siswa pada tiap siklusnya baik secara individu maupun klasikal dan adanya peningkatan kemampuan setelah diberikan tindakan (menerapkan metode penemuan terbimbing dengan mengoptimalkan penggunaan lembar kerja siswa (LKS) pada proses pembelajaran Matematika.

\section{HASIL PENELITIAN}

\section{Kondisi Awal}

Pada tahap ini peneliti hanya mengumpulkan data hasil pembelajaran yang dilaksanakan sebelumnya yaitu tanpa menggunakan metode penemuan terbimbing dengan mengoptimalkan penggunaan lembar kerja siswa (LKS). Bahwa pada kondisi awal siswa yang mendapatkan nilai sama dengan atau di atas nilai KKM adalah 23 orang dari seluruh siswa yang berjumlah 37 orang atau jika dipersentase $62,16 \%$, maka tingkat ketidaktuntasan secara klasikal siswa masih 37,84\%, sedangkan siswa dikatakan tuntas secara klasikal bila sudah mencapai $85 \%$ dari jumlah siswa. 


\section{Siklus I}

\section{a. Perencanaan}

Pelaksanaan siklus I ini dilaksanakan 2 kali pertemuan yaitu pada tanggal 2-14 September 2019 selama 4 x jam pelajaran (4x35 menit) dengan materi operasi hitung campuran. Pada tahap awal ini peneliti bersama guru teman sejawat (guru mitra) berdiskusi tentang permasalahan yang ada di kelas VI SD Negeri 39 Mataram. Setelah peneliti mengetahui permasalahan yang ada, peneliti berusaha menerapkan metode penemuan supaya dapat meningkatkan hasil belajar. Adapaun hal-hal yang dipersiapkan oleh peneliti yaitu mempersiapkan perangkat pembelajaran yang terdiri dari Rencana Pelaksanaan Pembelajaran (RPP), materi pelajaran, lembar kerja siswa (LKS), soal tes formatif dan instrument observasi aktivitas guru dan siswa serta alatalat yang diperlukan selama kegiatan belajar berlangsung.

\section{b. Pelaksanaan}

Pada tahap pelaksanaan siklus I ini peneliti bertindak sebagai guru dan dibantu oleh teman sejawat sebagi guru mitra. Adapun kegiatan pembelajaran yang dilaksanakan meliputi kegiatan awal, kegiatan inti, dan kegiatan penutup.

Pada kegiatan awal ini kelas dimulai dengan salam dilanjutkan dengan do'a. Guru mengkondisikan siswa untuk siap menerima pelajaran. Menyanyikan salah satu lagu wajib dan atau nasional. Pembiasaan membaca/menulis. Apersepsi yaitu menggali pemahaman siswa tentang materi operasi hitung campuran. Guru menyampaikan tujuan pembelajaran yang akan dicapai dan menyampaikan metode pembelajaran yang akan digunakan.

Selanjutnya kegiatan inti di mulai dengan siswa mencermati pengertian penjumlahan dan pengurangan bilangan pecahan. Menjelaskan cara menyelesaikan masalah penjumlahan dan pengurangan bilangan pecahan. Guru memberikan kesempatan kepada siswa untuk bertanya tentang materi yang disampaikan Guru menjelasakan pertanyaan siswa. Siswa mencoba berdiskusi dengan temannya tentang penjumlahan dan pengurangan bilangan pecahan. Guru menunjuk beberapa siswa untuk maju dan menjelaskan hasil diskusi tentang pengurangan dan penjumlahan bilangan cacah dengan bimbingan guru. Guru membentuk siswa menjadi 6 kelompok. Guru membagikan lembar kerja siswa (LKS) pada masing-masing 
kelompok. Guru memberikan soal latihan pecahan biasa kepada siswa. Guru mengamati siswa mengerjakan latihan soal terbimbing untuk dikerjakan dan dikumpul. Siswa mempresentasikan secara lisan kepada teman-temanya tentang penjumlahan dan pengurangan bilangan pecahan. Guru bersama siswa membahas latihan soal yang dianggap sulit oleh siswa. Guru memberi kesempatan siswa untuk bertanya. Guru memberi penguatan.

Kegiatan penutup di lakukan untuk mengambil kesimpulan siswa melakukan perenungan dengan menjawab pertanyaan yang terdapat dalam Buku Siswa. Guru dapat menambahkan pertanyaan perenungan berdasarkan panduan yang terdapat pada lampiran Buku Guru. Siswa melakukan perenungan dengan menjawab pertanyaan yang terdapat dalam Buku Siswa. Guru dapat menambahkan pertanyaan perenungan berdasarkan panduan yang terdapat pada lampiran Buku Guru. Siswa diminta berdiskusi bersama orang tua bagaimana cara menyelesaikan masalah penjumlahan dan pengurangan bilangan pecahan. Siswa menyampaikan hasilnya kepada guru. Menyanyikan salah satu lagu daerah untuk menumbuhkan. Salam dan doa penutup dipimpin oleh salah satu siswa.

\section{c. Observasi}

Sesuai dengan tujuan penelitian tindakan kelas untuk memperbaiki proses belajar mengajar, maka untuk memperoleh informasi atau data yang terjadi selama proses pembelajaran perlu dilakukan observasi untuk mengetahui apakah pembelajaran yang dilaksanakan telah memenuhi indikator yang diharapkan atau belum. Observasi ditujukan kepada guru dan siswa oleh satu orang guru observer. Observer guru dilaksanakan oleh $\mathrm{Hj}$. Sahnim.

Hasil aktivitas guru dalam proses kegiatan pembelajaran dengan metode penemuan pada siklus I, jumlah skor yang diperoleh 56 dan skor maksimumnya adalah 72. Dengan demikian prosentase skornya adalah $77,78 \%$ dan termasuk kategori baik. Sedangkan hasil observasi aktivitas siswa yang dilaksanakan oleh peneliti dalam mengikuti pembelajaran pada siklus I diperoleh skor 57 sedangkan skor maksimumnya adalah 72. Dan hasil prosentasinya adalah 79,17\% yang berarti aktivitas siswa selama mengikuti kegiatan pembelajaran berada dalam kategori baik. Hasil Belajar Matematika Siswa Kelas VI SD Negeri 39 Mataram yaitu dari seluruh siswa yang berjumlah 37 orang, siswa yang mencapai nilai sama dengan 
atau diatas nilai KKM adalah 29 orang siswa dan apabila dipersentase adalah $78,38 \%$, sedangkan pada kondisi awal hanya 23 orang siswa atau $62,16 \%$.

\section{d. Refleksi}

Kegiatan refleksi ini peneliti menyampaikan terlebih dahulu hasil observasinya tentang hal-hal yang masih dirasa kurang, kemudian observer juga diberi kesempatan yang sama sehingga memunculkan diskusi singkat antara guru peneliti dan observer guna mencari solusi untuk memperbaiki proses pembelajaran ke arah yang lebih baik.

\section{Siklus II}

\section{a. Perencanaan.}

Pada tahap perencanaan siklus II ini didasarkan pada perencanaan yang terdapat pada siklus I. Pada siklus II ini peneliti lebih meningkatkan kegiatan pembelajaran. Adapaun persiapan-persiapan yang dilakukan oleh peneliti yaitu mempersiapkan perangkat pembelajaran yang terdiri dari Rencana Pelaksanaan Pembelajaran (RPP), materi, lembar kerja,soal tes formatif dan instrument observasi aktivitas guru dan siswa serta alat - alat yang diperlukan selama kegiatan belajar berlangsung.

\section{b. Pelaksanaan.}

Pelaksanaan tindakan siklus II dilaksanakan pada tanggal 16-28 September 2019 untuk pertemuan ketiga dan pertemuan keempat. Waktu dan tempat kegiatan dilakukan sesuai dengan rencana pelaksanaan pembelajaran yang telah dibuat sebelumnya.

Pada tahap pelaksanaan siklus II ini peneliti bertindak sebagai guru dan dibantu oleh teman sejawat sebagi guru mitra. Adapun kegiatan pembelajaran yang dilaksanakan meliputi kegiatan awal, kegiatan inti, dan kegiatan penutup.

Pada kegiatan awal ini kelas dimulai dengan salam dilanjutkan dengan do'a. Guru mengkondisikan siswa untuk siap menerima pelajaran. Menyanyikan salah satu lagu wajib dan atau nasional. Pembiasaan membaca/menulis. Apersepsi yaitu menggali pemahaman siswa tentang materi membandingkan dan mengurutkan bilangan pecahan. Setelah itu guru menyampaikan tujuan pembelajaran yang akan 
dicapai dan menyampaikan metode pembelajaran yang akan digunakan.

Selanjutnya kegiatan inti di mulai dengan siswa mencermatI masalah membandingkan dan mengurutkan bilangan pecahan. Guru menjelaskan cara menyelesaikan masalah terkait membandingkan dan mengurutkan bilangan pecahan. Siswa mencermatI masalah membandingkan dan mengurutkan bilangan pecahan. Guru menjelaskan cara menyelesaikan masalah terkait membandingkan dan mengurutkan bilangan pecahan. Guru memberikan kesempatan kepada siswa untuk bertanya tentang materi yang disampaikan. Guru menjelasakan pertanyaan siswa. Siswa mencoba berdiskusi dengan temannya tentang membandingkan dan mengurutkan bilangan pecahan. Guru menunjuk beberapa siswa untuk maju dan menjelaskan hasil diskusi tentang membandingkan dan mengurutkan bilangan pecahan dengan bimbingan guru. Guru membentuk siswa menjadi 6 kelompok. Guru membagikan lembar kerja siswa (LKS) pada masing-masing kelompok. Guru memberikan soal latihan pecahan biasa kepada siswa. Guru mengamati siswa mengerjakan latihan soal terbimbing untuk dikerjakan dan dikumpul. Siswa mempresentasikan secara lisan kepada teman-temanya tentang membandingkan dan mengurutkan bilangan pecahan. Guru bersama siswa membahas latihan soal yang dianggap sulit oleh siswa. Guru memberi kesempatan siswa untuk bertanya. Guru memberi penguatan.

Kegiatan penutup di lakukan untuk mengambil kesimpulan siswa melakukan perenungan dengan menjawab pertanyaan yang terdapat dalam Buku Siswa. Guru dapat menambahkan pertanyaan perenungan berdasarkan panduan yang terdapat pada lampiran Buku Guru. Siswa melakukan perenungan dengan menjawab pertanyaan yang terdapat dalam Buku Siswa. Guru dapat menambahkan pertanyaan perenungan berdasarkan panduan yang terdapat pada lampiran Buku Guru. Siswa diminta berdiskusi bersama orang tua bagaimana cara menyelesaikan masalah penjumlahan dan pengurangan bilangan pecahan. Siswa menyampaikan hasilnya kepada guru. Menyanyikan salah satu lagu daerah untuk menumbuhkan. Salam dan doa penutup dipimpin oleh salah satu siswa. 


\section{c. Observasi}

Hasil observasi aktivitas guru dalam proses kegiatan pembelajaran dengan metode penemuan pada siklus II, jumlah skor yang diperoleh 69 dan skor maksimumnya adalah 72. Dengan demikian prosentase skornya adalah 95,83\% dan termasuk kategori sangat baik.

Hasil observasi aktivitas siswa yang dilaksanakan oleh peneliti dalam mengikuti pembelajaran pada siklus II diperoleh skor 66 sedangkan skor maksimumnya adalah 72. Dan hasil prosentasinya adalah $91,67 \%$ yang berarti aktivitas siswa selama mengikuti kegiatan pembelajaran berada dalam kategori sangat baik. Hal ini berarti bahwa dalam proses belajar mengajar siswa terlihat aktif dan antusias dalam mengikuti kegiatan belajar.

Hasil Belajar Matematika siswa Kelas VI SD Negeri 39 Mataram pada siklus II diperoleh nilai rata-rata 83,89 dan ketuntasan belajar mencapai 91,89\% atau ada 34 siswa yang tuntas belajar. Hasil tersebut menunjukkan bahwa pada siklus II secara klasikal siswa sudah tuntas belajar, karena siswa yang memperoleh nilai $>77$ sebesar $91,89 \%$ lebih besar dari prosentase ketuntasan yang dikehendaki yaitu 85\%, sehingga penelitian ini sudah tuntas pada siklus II.

\section{d. Refleksi.}

1) Hasil pengamatan peneliti terhadap aktifitas guru dalam mempertahankan dan meningkatkan suasana pembelajaran yang mengarah pada metode penemuan, telah mencapai kriteria keberhasilan 95,83\% berada dalam kategori sangat baik. Ini berarti bahwa kriteria keberhasilan aktifitas guru mata pelajaran Matematika dalam pembelajaran pada siklus II telah berhasil dengan baik.

2) Hasil pengamatan peneliti terhadap aktifitas siswa dalam kegiatan pembelajaran telah mencapai kriteria keberhasilan 91,67\%. Berada dalam katagori sangat baik. Ini berarti bahwa kriteria keberhasilan siswa dalam pembelajaran dalam siklus II telah berhasil dengan baik.

3) Hasil pengamatan guru terhadap hasil belajar siswa pada mata pelajaran Matematika mencapai ketuntasan 91,89\% dan nilai evaluasi akhir rata-rata 83,89. Sedangkan nilai standart kompetensi minimal mata pelajaran Matematika adalah minimal 77. Hal ini berarti siswa sudah berhasil dalam mencapai standart nilai 
yang telah ditetapkan.

4) Pada saat pembelajaran siklus II suasana sudah banyak terjadi perubahan, karena kegiatan diskusi dalam materi benda-benda konduktor dan benda-benda isolator panas, semua siswa berpartisipasi aktif untuk menyelesaikan tugas yang diberikan.

5) Pembelajaran dengan metode penemuan ternyata membawa dampak positif terhadap aktifitas belajar siswa.

6) Siswa semakin akrab dan sudah berani bertanya kepada teman kelompoknya atau gurunya apabila ada hal-hal yang belum dimengerti.

Dari beberapa hasil pengamatan selama penelitian, peneliti bersama guru mata pelajaran Matematika menyimpulkan bahwa pelaksanaan tindakan selama siklus II sudah berhasil dengan baik, untuk itu tidak perlu lagi diulang pada tindakan siklus yang ke tiga.

\section{KSIMPULAN}

1. Metode penemuan terbimbing dapat meningkatkan hasil belajar Matematika materi operasi hitung campuran pada siswa kelas VI SD Negri 39 Mataram. Hasil belajar Matematikan mengalami peningkatan dengan ketuntasan belajar 61,16\% pada kondisi awal menjadi 78,38\% pada siklus I menjadi $91,89 \%$ pada siklus II ketuntasan belajar siswa secara klasikal telah tercapai.

2. Dari aktivitas siswa mengalami peningkatan, aktivitas siswa meningkat dari skor perolehan 79,17\% pada siklus I, menjadi 91,67\% pada siklus II. Berdasarkan analisis data, diperoleh aktivitas siswa dalam proses pembelajaran Matematika dengan metode penemuan terbimbing yang paling dominan adalah bekerja dengan menggunakan alat/media, mendengarkan/memperhatikan penjelasan guru, dan diskusi antar siswa/antara siswa dengan guru. Jadi dapat dikatakan bahwa aktivitas siswa dapat dikategorikan aktif.

3. Sedangkan aktivitas guru meningkat dari skor perolehan $77,78 \%$ pada siklus I, menjadi 95,83\% pada siklus II. Untuk aktivitas guru selama pembelajaran telah melaksanakan langkah-langkah metode penemuan terbimbing dengan mengoptimalkan penggunaan LKS dengan baik. 


\section{SARAN}

Berdasarkan hasil penelitian yang sudah dilaksanakan peneliti di SD Negri 39 Mataram dengan metode penemuan terbimbing, maka peneliti memberikan saran sebagai berikut:

1. Waktu melaksanakan pembelajaran dengan metode penemuan terbimbing hendaknya guru memberikan penjelasan materi mencari rumus luas bangun datar yang jelas agar siswa dapat memahami bagaimana cara menemukan pengetahuannya sendiri sehingga diharapkan aspek kognitif siswa dapat meningkat.

2. Pada saat siswa mendiskusikan lembar penemuan untuk mencari luas bangun datar sebaiknya guru sering berkeliling untuk melihat pekerjaan siswa dan aktif menanyakan hal-hal yang belum dapat dipahami siswa sehingga siswa ikut aktif dalam tanya jawab dalam kelompok dan sikap afektif siswa dapat meningkat

3. Sewaktu siswa menggunakan alat peraga untuk mencari rumus bangun datar sebaiknya guru memberikan arahan yang mudah dipahami siswa sehingga siswa dapat berperan aktif dan terampil dalam menggunakan alat peraga. Hal ini diharapkan agar aspek psikomotorik siswa dapat meningkat.

4. Disarankan kepada sekolah agar melakukan pemantapan kegiatan guru untuk melihat kemungkinan kesulitan di kelas, dan mendiskusikannya sehingga dapat ditangani secara bersama serta mengajak dan menganjurkan guru untuk melakukan penelitian tindakan kelas.

\section{DAFTAR PUSTAKA}

Effendi Sofian. 2012. Metode Penelitian Survei.Jakarta:LP3ES .

Faizi, 2013. Ragam Metode Mengajarkan Eksakta Pada Murid. Yogyakarta: DIVA Press.

Kemendikbud .2013. Proses revisi Kurikulum 2013 (K-13). Jakarta, Kemendikbud.

Suharsimi Arikunto. 2012. Penelitian Tindakan Kelas. Jakarta: PT. Bumi Aksara. Slameto. 1998. Belajar dan Faktor-Faktor yang Mempengaruhinya, Jakarta,. Bina Aksara. 